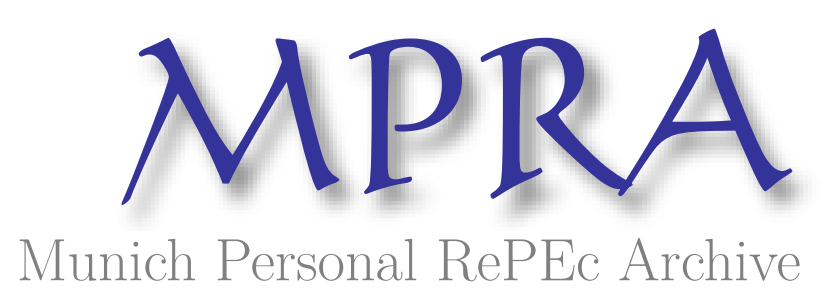

\title{
Financial Engineering and Engineering of Financial Regulation
}

Coskun, Yener

Conference on Financial Engineering

21 October 2011

Online at https://mpra.ub.uni-muenchen.de/34838/

MPRA Paper No. 34838, posted 18 Nov 2011 16:04 UTC 
Conference on Financial Engineering

Izmir University of Economics

Izmir, Turkey, 20-21 October 2011

\title{
Financial Engineering and Engineering of Financial Regulation
}

\author{
WORKING PAPER
}

\section{Yener COŞKUN}

October, 2011 


\title{
Financial Engineering and Engineering of Financial Regulation*
}

\author{
Yener COŞKUN** \\ Senior Specialist \\ Capital Markets Board of Turkey
}

20 October 2011

\begin{abstract}
As observed at least in last two decades, financial engineering has not only changed the way of doing business in finance world, but also has changed daily life of average citizens in the leading economies. Structured products named as weapons of mass destruction in some post-crisis comments. But it is fair to say that few people could understand the nature and risks of these instruments before the crisis. By using literature review and case study analysis, the author analyses how financial regulation and supervision have failed to understand/manage the financial engineering products during/before the global financial crisis. In this context, we discuss the measures to enhance good regulatory governance in engineered products. We conclude however engineered products have important benefits to the global economy, regulatory/supervisory structure should be improved for better firm/system wide risk management. Secondly, there are four components to improve prudential regulatory/supervisory framework of structured products. Those are, timely/effectively action to the balance sheet problems, to increase the effectiveness of the risk management, to improve independence and quality of prudential regulation/supervision and to increase accountability of supervisors.
\end{abstract}

Keywords: Financial engineering, structured finance, financial crisis, risk management, regulation. Jel Classification: G32, G01, G24, G38

\footnotetext{
* This paper is partly based on the ongoing PhD research of Yener Coşkun. Opinions expressed in this study are of author's and do not necessarily represent the institutions connected with the author. You may quote or cite with consent of the author.

** Yener Coşkun, MRICS, is PhD Candidate, Ankara University The Graduate School of Natural and Applied Sciences, Real Estate Development Department. Address: Eskişehir Yolu 8.Km No:156 06530 Ankara/Turkey. Phone:(+90 312) 29288 24; e-mail:ycoskun@ spk.gov.tr; Web-site: http://ankara.academia.edu/yenercoskun
} 


\section{INTRODUCTION}

Fundamental reason of the subprime mortgage crisis is related to global imbalances among countries classified as to save/consumpt more/less. There are also secondary reasons of the crisis such as problems of the originate and distribute model, inefficiencies in firm/system wide risk management practices, asymmetric information problem, ineffective regulatory/supervisory structure of the U.S. financial system etc. However this picture reminds us the problems of previous financial crisis/failures, we still need to analyse the new financial failure stories.

Problems observed in financial engineering products may be accepted as one of the important reasons of the global financial crisis due to various reasons.

These products/transactions seem like a double-edged sword. On the one hand, structured products help to improve efficiency in financial markets by reducing the costs of funding. Therefore, engineered products help to increase volume of housing credits while reducing cost of borrowing. It can be observable that mortgage affordability has improved before the crisis due to technological improvements, financial innovations, positive economic environment, subsidies, and low cost housing credits. Improving affordability means better economic/financial environment to realize American dream which has been at top of the agenda of U.S. politicians, households and finance industry. But on the other hand, structured finance products were in the center of financial failures during the crisis period. Basically, the mechanism of these products was one of the determinants of mipricing the risks in primary/secondary mortgage markets. This valuation problem is institutionally related to all market participants involving appraisal firms, originators, financial intermediaries (i.e. investment banks, mortgage brokers, insurance companies etc.), state/federal level regulators, market discipline instiutions (i.e. CRAs, auditors, analysts, accounting firms etc.), investors etc. It is not surprise to note that problems of financial engineering are the catalyst in the process of subprime and eventually global financial crisis.

By using literature review and case study analysis, the author analyses how financial regulation/supervision have failed to understand/manage the financial engineering products during/before the global financial crisis. In this context, we discuss the measures to enhance good regulatory governance for financial engineering systems.

The paper is organized in five further sections. The paper starts with a discussion of the relationship between financial engineering and market fundamentalism. In section three, we describe benefits and risks of financial engineering. The fourth section considers global financial crisis and regulatory failures related to financial engineering. The fifth section reviews problem of regulatory forbearance and determinants of effective regulatory framework for financial engineering. And last section is reserved for the conclusion remarks.

\section{Financial Engineering and Market Fundamentalism}

Financial engineering is a practice and can be used only when we define the related environment carefully (Neftçi, 2008: 23). The philosophy and/or socio-politic environment caused evolving financial engineering products may be defined by some magic liberal words involving free market economy, economic freedom, financialization etc. Because the approach of ultra liberalisation has impaired regulatory/supervisory systems, one may raise the question after global financial crisis whether "feel free" market economy is sufficient enough to sustain global economy. 
[In the process of deregulation,] investors became fearless and driven only by greed; regulators slept at the wheel, taking comfort from the self-regulating and self-corrective capacity of efficient markets. There was an overt display of triumphalism about invincibility of Western financial capitalism (Hu, 2010: 31).

In the period of post 2000's, financial deregulation, shadow banking and also investment banking were the rising stars in the leading financial centres. In addition to market players, regulators and also politicians do believe the benefits of financial engineering through structured products and securitisation techniques. But, according to various observers, free market fundamentalism is clearly one of the reasons of global financial crisis. For example, Hutton (2010: 33) indicates that this crisis was thirty years in the making - a Gordian knot of libertarian free-market fundamentalism, unregulated globalisation, the collapse of social and political force committed to fairness, the explosive impact of financial innovations such as "securitisation", and sheer greed (also, see Levy, 2010: 47).

One may also note that positive market environment have made critical contributions to the housing bubble. In this context, federal level housing ownership policies in the US, ${ }^{1}$ interest rate policies of FED, specifically between $2003-2007,{ }^{2}$ various mortgage subsidies and the role of GSEs, easy credit policies of mortgage finance institutions, fast securitisation process etc. have made housing loans easily accessible to lower income groups/minorities (subprime borrowers). In this picture, we may argue that both market environment and government policies have provided credit to financial engineering practices.

\section{Benefits and Risks of Financial Engineering}

It has been observed that politicians/bureaucrats in the US did not have reactionary approach against financial engineering products because of two reasons. First, not surprisingly, they did not exactly understand the risks of structured products. This can be acceptable because even highly sophisticated market participants (i.e. CRAs, investment bankers, "typically" many board members etc.) couldn't understand the realities. ${ }^{3}$ As an interesting comment Pacek (2010: 73-74) indicates that a lot of garbage, now commonly refer to as toxic waste, was packaged into sexy-sounding names. CRAs happily rated them triple A and unsuspecting buyers were told they were buying great stuff that could never fail, was secure and gave a good return.

Second, and more importantly, they thought that financial engineering products help to improve mortgage affordability. Therefore, they believe that more securitization and hence higher volume of low-cost housing credits would make American dream more reliable. Side benefits of this process were also fantastic. Thanks to financialization and positive wealth effect, this mechanism also created better macro economic environment (i.e. positive real economic growth, increasing employment etc.) in the U.S. economy in between 2003-2007 and hence minimized negative impacts of stock market bubble. If the risks would not mispriced in the process of engineering (specifically in the case of securitization) and housing

\footnotetext{
${ }^{1}$ The housing boom, which got started as early as 1997 and peaked only after ten long years, expressed a neurotic obsession with home ownership (Phelps, 2010: 78). Home ownership, may be also related to ownership culture of the U.S., has also strong support from politicians and finance sector.

${ }^{2}$ Lyons (2010: 53) indicates that lower interest rates contributed the collective greed.

${ }^{3}$ Paradoxically, this "total failure" story may be already well known from the Enron case. In this regard, Gillan and Martin (2002) suggest that management used financial engineering and related-party transactions to disguise Enron's financial condition for over three years. These transactions, board approved, sanctioned by the external auditor, and partially disclosed in SEC filings, put the firm on an economic precipice of which few were aware.
} 
prices would continue to rise, one may do believe that the above picture might work longer time.

The new forms of financial engineering designed to spread and minimise the risks had made much greater leverage possible (Bruton, 2010: 9). For example, securitisation and the use of credit derivatives were thought to disperse risk in ways that reduced overall risk levels (Feldstein, 2010: 17). The financial revolution of the last two decades has registered large potential gains in dealing with risk; but most of this gain has been swallowed by the rising costs of financial intermediation, made possible by monopoly and asymmetric information resources, and generated by escalating marketing and trading expenditures as well as extravagant remuneration (Blackburn, 2006: 40-41). While financial engineering can bring great rewards to its practitioners, many of its most characteristic devices have nothing to do with improved performance, but are all about gaming the taxman or the shareholders (Blackburn, 2006: 66).

\section{Global Financial Crisis and Regulatory Failures in Financial Engineering}

The world struggles to cope with capitalism's near apocalyptical failure (Fernandes, 2010: 20). It seems that global financial crisis will probably the milestone of everything in the near future from finance industry, politics, art market to global poverty.

In many respects, the subprime market experienced a classic lending boom-bust scenario with rapid market growth, loosening underwriting standards, deteriorating loan performance, and decreasing risk premiums. Argentina in 1980, Chile in 1982, Sweden, Norway, and Finland in 1992, Mexico in 1994, Thailand, Indonesia, and Korea in 1997 all experienced the culmination of a boom-bust scenario, albeit in different economic settings. But, rapid appreciation in housing prices masked the deterioration in the subprime mortgage market and thus the true riskiness of subprime mortgage loans. When housing prices stopped climbing, the risk in the market became apparent (Demyanyk and Hemert, 2008: 32-33).

Most economists and financial analysts identify amongst the main causes of the current global financial crisis, the U.S. Federal Reserve's low interest rates policy (Fed funds) of the latest years with the resulting credit euphoria of both lenders and borrowers, the more "relaxed" credit initiation policies and procedures, the overwhelmingly positive expectations on the real estate market growth and prices increases, and the massive use of badly controlled innovative financial engineering tools (Pezzuto, 2008: 4).

As seen in the new regulations of U.S., the negative impacts of financial engineering have accepted as one of important reasons of the crisis. The motives of profit-making, shorttermism and competition are among the essential elements of single/systemic failures occured in various mortgage finance institutions during the crisis. But it is equally essential to note that regulatory/supervisory agencies from UK to US have also failed during the global turmoil. From regulatory point of view, we may argue that lack of efficient regulatory/supervisory structure related to engineered products is one the critical reasons of the regulatory failure.

Therefore, it is obvious that failures in valuation/accounting/reporting of complicated structured products are also related to failures of regulatory/supervisory organisations (See, Coskun, 2010: 79). In this context, asymmetric information problem grows in the process of global financial crisis due to various reasons. First, lack of sufficient regulatory/supervisory measures againts the risks of structured products have caused more risky market environment. 
Second, informational asymmetry also grows due to lack of sufficient transparency in the structured finance products. Third, independent audit firms and also credit rating agencies haven't performed their responsibilities.

\section{Regulatory Forbearance and Effective Regulatory Framework for Financial Engineering}

As a general establishment, supervisors and regulators have the ultimate responsibility for both firm-wide and industry-wide risk management practices due to their statutory objectives. In this context, regulators aim to enhance firm level control and discipline mechanism and not only accounting, internal control and internal audit mechanisms but also risk management system are also shaped by regulators and supervisors (Coskun, 2007: 56).

It has been long recognized that financial engineering works without effective official discipline framework. In other words, regulation/supervision/enforcement tools have not simultaneously worked well in the case of structured finance during/before the crisis. To regulate some structured products have some limitations, ${ }^{4}$ but it seems that the instruments of regulation and supervision have failed in the case of financial engineering. ${ }^{5}$

Existing literature suggests that regulatory problems, also involving regulatory forbearance, is one of the biggest issues with previous financial crisis in the U.S. For example, Das and Quintyn (2002) suggest that in nearly all financial crises of the past decade-East Asia, Ecuador, Mexico, Russia, Turkey and Venezuela- political interference in the regulatory and supervisory process, forbearance, weak regulations, and supervision have been mentioned as contributing factors to the depth and size of the systemic crises. Kawai et al. (2003) argue that in the run up to the crisis, East Asian banks developed large asset-liability mismatchesunhedged foreign exchange borrowings invested in non-tradable sectors and short-term funds lent long into property - all of which left the banks vulnerable to exchange depreciations and to interest rate surges. This vulnerability reflected the fact that domestic financial systems were not well-regulated or governed when capital account liberalization was accelerated in the first half of the 1990s. Regulatory and supervisory frameworks over financial institutions were weak in risk-management and the capital base-together with loan classification and loan loss provisions. Moral hazard was created because of explicit or implicit government guarantees to individual financial institutions.

Quintyn and Taylor (2002) emphasize that two factors served to give the need for regulatory and supervisory independence greater prominence in recent years. First in almost all of the systemic financial crises of the 1990s, the lack of independence of supervisory authorities from political influence has been cited as one of the contributing factors to the deepening of the crisis. Weak and ineffective regulations - often because politicians block the adoption of stronger regulations- weak and dispersed supervision, and political interference in the supervisory process leading to regulatory forbearance have been mentioned as major factors contributing to the weakening of the banks in the run-up to the crisis, postponing the

\footnotetext{
${ }^{4}$ For example more transparency in OTC market/derivatives trading may support over reaction and hence increase risks of single/systemic failures. Additionally, it is very clear that average financial services consumers (and even more sophisticated players) may not easily understand the real risks of the OTC/derivatives transactions. On the other hand, financial firms dealing with OTC market/derivatives trading may avoid disclosing OTC/derivatives trading information to protect proprietary information, to preserve competitive advantage and also to avoid legal problems (Coskun, 2011: 130-131).

${ }^{5}$ An analysis for the limitations of financial engineering in emerging countries, see, Hill (2000).
} 
recognition of the severity of the crisis, and delaying first official and subsequently effective intervention.

It is important to enhance accountability of regulators to prevent/minimize regulatory problems. Mishkin (2001) points out that supervisor must be accountable if they engage in regulatory forbearance in order to improve incentives for them to do their job properly. To get supervisors to do their jobs properly, they must also be subject to criminal prosecution if they are caught taking bribes and must also be subject to censure and penalties if they take jobs with institutions that they have supervised recently.

In this context, we may argue that one of the factors contributing the subprime mortgage crisis is lack of efficient regulatory/supervisory framework. In this context, it is observable that U.S. regulators haven't showed effective reaction to the crisis. For example in the case of SEC, it is very clear that there was no efficient systemic risk management policies for both financial institutions (i.e. hedge funds, investment banks, CRAs etc.) and also financial products (i.e. structured products). On the other hand, existing literature also indicates that problems in other governmental organisations (i.e. FED, GSEs, FHA etc.) and weaknessess in the orchestration of the official discipline system did also impair systemic risk management. Therefore, it is specifically clear that riskier lending practices and risks of securitized/structured products were not effectively managed by the regulators/supervisors.

In the light of problems observed during the global financial crisis, we may define a framework to improve current regulatory system on financial engineering practices. To keep the discussion within limits, we will only underline the components of good regulatory/supervisory governance for financial engineering products. Das and Quintyn (2002) suggest that there are four components of good regulatory governance. These include (i) independence of the agency from political and industry interference; (ii) accountability; (iii) transparency; and (iv) integrity. In this context, sound prudential regulatory/supervisory system may have four components.

1) Timely/effectively action to balance sheet problems of all financial intermediaries.

2) To increase the effectiveness of the risk management.

3) To improve independence and quality of prudential regulation/supervision.

4) To increase accountability of supervisors.

This study does not claim to provide the full picture of relationship between subprime mortgage crisis and regulatory/supervisory problems of financial engineering products. But we identified room for enhancing regulatory framework for financial engineering.

\section{CONCLUSION}

In this paper, we consider how financial regulation and supervision have failed to understand/manage the financial engineering products during/before the global financial crisis. In this context, we discuss the measures to enhance good regulatory governance in engineered products.

It has been observed that politicians/bureaucrats in the US did not have reactionary approach against financial engineering products because of two reasons. First, not surprisingly, they did not exactly understand the risks of structured products. This can be acceptable because even highly sophisticated market participants (i.e. CRAs, investment bankers, "typically" many board members etc.) couldn't understand the realities. Second, and more importantly, they 
thought that financial engineering products help to improve mortgage affordability. Therefore, they believe that more securitization and hence higher volume of low-cost housing credits would make American dream more reliable.

It has been long recognized that financial engineering works without effective official discipline framework. In other words, regulation/supervision/enforcement tools have not simultaneously worked well in the case of structured finance during/before the crisis. To regulate some structured products have some limitations, but it seems that the instruments of regulation and supervision have failed in the case of financial engineering.

In this context, we may argue that one of the factors contributing the subprime mortgage crisis is lack of efficient regulatory/supervisory framework. In this context, it is observable that U.S. regulators haven't showed effective reaction to the crisis. For example in the case of SEC, it is very clear that there was no efficient systemic risk management policies for both financial institutions (i.e. hedge funds, investment banks, CRAs etc.) and also financial products (i.e. structured products). On the other hand, existing literature also indicates that problems in other governmental organisations (i.e. FED, GSEs, FHA etc.) and weaknessess in the orchestration of the official discipline system did also impair systemic risk management. Therefore, it is specifically clear that riskier lending practices and risks of securitized/structured products were not effectively managed by the regulators/supervisors.

We conclude however engineered products have important benefits to the global economy, regulatory/supervisory structure should be improved for better firm/system wide risk management. Secondly, there are four components to improve prudential regulatory/supervisory framework of structured products. Those are, timely/effectively action to the balance sheet problems, to increase the effectiveness of the risk management, to improve independence and quality of prudential regulation/supervision and to increase accountability of supervisors.

\section{REFERENCES}

Blackburn, R. 2006. Finance and the Fourth Dimension. New Left Review (May-June): 39-70.

Bruton, J. 2010. (in, The Future of Money, 2010, Ed.: Chittenden, O., Virgin Books, UK): 9-11.

Coşkun, Y. 2007. Self Discipline in Financial Institutions. CMB Publications (No: 205).

Coşkun, Y. 2010. Structured Finance and Global Financial Crisis. Finans Politik \& Ekonomik Yorumlar Journal 47 (545): 71-80.

Coşkun, Y. 2011.The Limitations of Transparency Policy in OTC Markets and Derivatives Trading. Journal of Securities Operations \& Custody 4 (2): 122-133.

Das, U. S. and Quintyn, M. G., 2002, Crisis Prevention and Crisis Management: The Role of Regulatory Governance, IMF Working Paper, WP/02/163 (Washington, International Monetary Fund).

Demyanyk, Y.S. and Hemert, O.V. 2008. Understanding the Subprime Mortgage Crisis. December 5. Available at: http://papers.ssrn.com/sol3/papers.cfm?abstract_id=1020396 (08.09.2011).

Feldstein, M. 2010. (in, The Future of Money, 2010, Ed.: Chittenden, O., Virgin Books, UK): 15-19.

Fernandes, T. 2010. (in, The Future of Money, 2010, Ed.: Chittenden, O., Virgin Books, UK): 20-23.

Hill, C. A. 2000. The Promise and Limits of Financial Engineering in Emerging Markets. Kluwer Academic Press, May. Available at SSRN: http://ssrn.com/abstract=213588 or doi:10.2139/ssrn.213588 (10.10.2011). 
Gillan, S.L. and Martin, J. D. 2002 Financial Engineering, Corporate Governance, and the Collapse of Enron. November. U of Delaware Coll. of Bus. and Econ. Ctr. for Corp. Governance Working Paper No. 2002-001. Available at SSRN: http://ssrn.com/abstract=354040 or doi:10.2139/ssrn.354040 (03.08.2011).

Hu, F. 2010. (in, The Future of Money, 2010, Ed.: Chittenden, O., Virgin Books, UK): 30-32.

Hutton, W. 2010. (in, The Future of Money, 2010, Ed.: Chittenden, O., Virgin Books, U.K.): 33-36.

Kawai, M., Newfarmer, R. and Schmukler, S.L. 2003 Financial Crises: Nine Lessons From East Asia, East Asian Bureau of Economic Research, Finance Working Papers No:482, May. Available at: http://ideas. repec. org / s / eab/financ.html (12.09.2011).

Levy, M. 2010. (in, The Future of Money, 2010, Ed.: Chittenden, O., Virgin Books, U.K.): 47-48.

Lyons, G. 2010. (in, The Future of Money, 2010, Ed.: Chittenden, O., Virgin Books, UK): 52-54.

Mishkin, F. S. 2001. Financial Policies and the Prevention Of Financial Crises in Emerging Market Countries, NBER Working Papers Series, Working Paper 8087, January.

Neftçi, N. S.208. Principles of Financial Engineering. Second Edition. Elsevier. Canada.

Pacek, N. 2010. (in, The Future of Money, 2010, Ed.: Chittenden, O., Virgin Books, U.K.): 72-74.

Pezzuto, I. 2008. Miraculous Financial Engineering or Toxic Finance? The genesis of the U.S. subprime mortgage loans crisis and its consequences on the global financial markets and real economy. Working Paper. Issue 12/2008. Swiss Management Center (SMC).

Phelps, E. 2010. (in, The Future of Money, 2010, Ed.: Chittenden, O., Virgin Books, UK): 75-78.

Quintyn, M. and Taylor, M.W. 2002, Regulatory and Supervisory Independence and Financial Stability, IMF Working Paper, WP/02/46, (Washington, International Monetary Fund). 